\title{
A competitive following association between two reef fishes and the Jewelled Moray in the Gulf of California, Mexico
}

Received: 7 April 2010/Accepted: 12 May 2010/Published online: 30 May 2010

(C) Springer-Verlag 2010

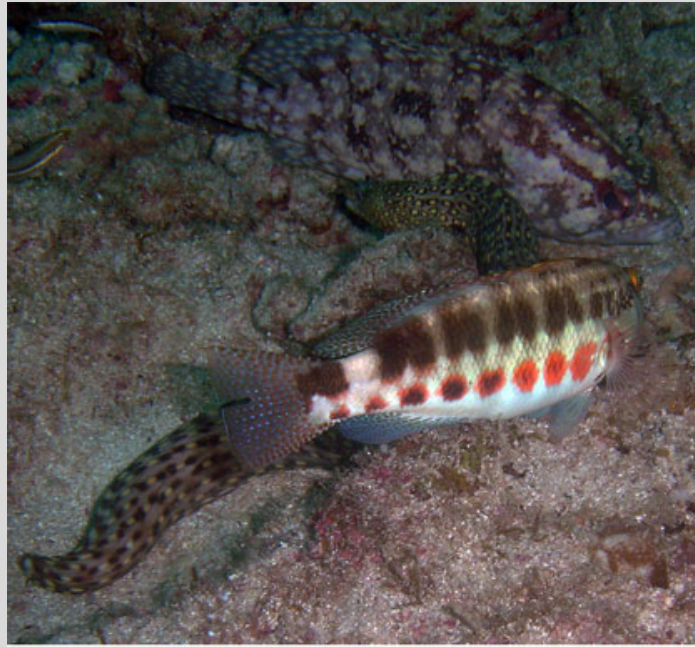

Following behaviour among marine fishes is a commonly observed phenomenon in which an "attendant" species keeps pace with a "nuclear" species in order to opportunistically feed on prey items uncovered or flushed out of hiding by the nuclear species. This association is thought to benefit the attendant species by providing access to prey not normally available. For the nuclear species, there is no apparent benefit, and this association may be detrimental in terms of loss of prey to the attendant (for a recent discussion of following behaviour in fishes, see Krajewski 2009). In this report, we document two heretofore unreported following associations between a grouper (Alphestes immaculatus Breder 1936), a seabass (Serranus psittacinus Valenciennes 1846) and an eel (Muraena lentiginosa Jenyns 1832) in the Gulf of California, Mexico.

During a reconnaissance dive at Suwanee Reef, which is located off the southeast coast of Espiritu Santo Island near La Paz, Baja California Sur, Mexico $\left(24^{\circ} 23^{\prime} 11.27^{\prime \prime} \mathrm{N} ; 110^{\circ} 18^{\prime} 52.10^{\prime \prime} \mathrm{W}\right)$, our attention was caught by an active, free swimming Jewelled Moray (Muraena lentiginosa). As the eel actively foraged among the substrate, it was closely followed by two reef fishes, the Pacific Mutton Hamlet (Alphestes immaculatus) and the Barred Serrano (Serranus psittacinus; Fig. 1). Both attendants stayed within $15 \mathrm{~cm}$ of the eel during foraging, and as prey was plucked from small crevices, would immediately descend on the eel's head and grab the prey item that was removed. When prey was encountered by the eel, both attendant species exhibited aggression towards each other and to the eel, indicating that all three species were in direct competition for the resource. The Pacific Mutton Hamlet exhibits some degree of territorial behaviour (Erisman 2008), and as the eel would move from one territory to another, the resident Mutton Hamlet would immediately engage in intraspecific aggression towards the invading conspecific. Following this aggression, the resident replaced the invader as the attendant individual. The Serrano, however, was apparently unmolested by the resident and allowed to continue its association. High-definition video of this behaviour may be viewed at http://www.momo-p.com/index-e.html.

Following associations that involve foraging may represent a significant contribution to the trophic structure of reef communities (Sazima et al. 2007). In the Gulf of California, such interactions comprise a significant proportion, up to $25 \%$, of the time budget of many reef species (Strand 1988). Although following associations in the Gulf of California have been well documented (e.g., Montgomery 1975), this report represents the first documentation of following between reef fishes and a member of the genus Muraena.

References

Erisman B (2008) Reproductive biology and evolution of epinephelid and serranid fishes (Perciformes, Epinephelidae, Serranidae). Ph.D. Thesis, University of California, San Diego, p 210

Fig. 1 Following of the Jewelled Moray by the Pacific Mutton Hamlet (background) and the Barred Serrano (foreground)

Krajewski J (2009) How do follower fishes find nuclear fishes? Environ Biol Fish 86:379-387

Montgomery W (1975) Interspecific associations of Sea-Basses (Serranidae) in the Gulf of California. Copeia 1975:785-787

Sazima C, Krajewski JP, Bonaldo RM, Sazima I (2007) Nuclear-follower foraging associations of reef fishes and other animals at an oceanic archipelago. Environ Biol Fish 80:351-361

Strand S (1988) Following behavior: interespecific foraging associations among Gulf of California reef fishes. Copeia 2:351-357

M. T. Craig (ه)

Department of Marine Sciences, University of Puerto Rico at Mayagüez, Mayagüez, PR 00683, USA

e-mail: matthew.craig@upr.edu

B. E. Erisman

Center for Marine Biodiversity and Conservation, Scripps Institution of Oceanography, La Jolla, CA 92093, USA

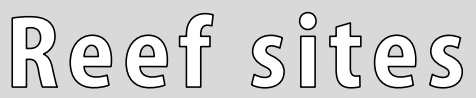

Coral Reefs (2010) 29:813 DOI $10.1007 / \mathrm{s} 00338-010-0641-2$ 